\title{
Gonadotropin-induced ovarian cancer cell migration and proliferation require extracellular signal-regulated kinase $1 / 2$ activation regulated by calcium and protein kinase $\mathbf{C} \delta$
}

\author{
Inga Mertens-Walker, Christine Bolitho, Robert C Baxter \\ and Deborah J Marsh
}

Hormones and Cancer Group, Kolling Institute of Medical Research, Royal North Shore Hospital, University of Sydney, E25, St Leonards, New South Wales 2065, Australia

(Correspondence should be addressed to D J Marsh; Email: deborah.marsh@sydney.edu.au)

\begin{abstract}
The gonadotropin hypothesis proposes that elevated serum gonadotropin levels may increase the risk of epithelial ovarian cancer (EOC). We have studied the effect of treating EOC cell lines (OV207 and OVCAR-3) with FSH or LH. Both gonadotropins activated the mitogen-activated protein kinase (MAPK)/extracellular signal-regulated kinase 1/2 (ERK1/2) pathway and increased cell migration that was inhibited by the MAPK 1 inhibitor PD98059. Both extra- and intracellular calcium ion signalling were implicated in gonadotropin-induced ERK1/2 activation as treatment with either the calcium chelator EGTA or an inhibitor of intracellular calcium release, dantrolene, inhibited gonadotropin-induced ERK1/2 activation. Verapamil was also inhibitory, indicating that gonadotropins activate calcium influx via L-type voltage-dependent calcium channels. The cAMP/protein kinase A (PKA) pathway was not involved in the mediation of gonadotropin action in these cells as gonadotropins did not increase intracellular CAMP formation and inhibition of PKA did not affect gonadotropin-induced phosphorylation of ERK1/2. Activation of ERK1/2 was inhibited by the protein kinase C (PKC) inhibitor GF 109203X as well as by the PKC $\delta$ inhibitor rottlerin, and downregulation of PKC $\delta$ was inhibited by small interfering RNA (siRNA), highlighting the importance of $\mathrm{PKC} \delta$ in the gonadotropin signalling cascade. Furthermore, in addition to inhibition by PD98059, gonadotropin-induced ovarian cancer cell migration was also inhibited by verapamil, GF 109203X and rottlerin. Similarly, gonadotropin-induced proliferation was inhibited by PD98059, verapamil, GF 109203X and PKC $\delta$ siRNA. Taken together, these results demonstrate that gonadotropins induce both ovarian cancer cell migration and proliferation by activation of ERK1/2 signalling in a calcium- and PKC $\delta$-dependent manner.
\end{abstract}

Endocrine-Related Cancer (2010) 17 335-349

\section{Introduction}

Ovarian cancer is the eighth most commonly diagnosed cancer in women and the most lethal of all the gynaecological malignancies, with a 5-year survival around 40\% (Jemal et al. 2008). Approximately 90\% of ovarian cancers are thought to arise from the ovarian surface epithelial (OSE) cell layer or fallopian tube fimbria, but little is known about their aetiology (Dubeau 2008). There is increasing evidence that the hormonal environment surrounding the ovaries can influence the development of ovarian cancer (Riman et al. 2004, Lukanova \& Kaaks 2005). One prominent hypothesis is that the gonadotropins FSH and LH enhance ovarian tumourigenesis, which is supported by the fact that ovarian cancer is more common in postmenopausal women in whom serum gonadotropin levels are elevated (Konishi 2006). Additionally, there is a pronounced decrease in the risk of developing epithelial ovarian cancer (EOC) in women using oral contraceptives for more than 10 years, having 
multiple pregnancies, or having prolonged lactation, all conditions associated with suppressed gonadotropins in the circulation (Gnagy et al. 2000, Modugno et al. 2004). Of significance, recent studies of ovarian cyst fluid from malignant and benign ovarian tumours have shown higher levels of FSH and LH in fluid from malignant versus benign tumours (Rzepka-Gorska et al. 2004, Thomas et al. 2008).

Numerous studies have shown that FSH in particular has a proliferative effect on normal and malignant OSE cell growth (Wimalasena et al. 1992, Parrott et al. 2001, Syed et al. 2001, Ji et al. 2004). However, studies have shown conflicting effects of LH on the growth of benign and malignant OSE cells (Zheng et al. 2000, Ivarsson et al. 2001, Syed et al. 2001). Little is known about the role of gonadotropins in other critical events of ovarian tumourigenesis, such as metastasis, although it has been shown that elevated FSH and LH may be important in increasing adhesion of EOC cells (Schiffenbauer et al. 2002). Furthermore, gonadotropins have been shown to promote invasion of ovarian cancer cells through the phosphatidylinositol 3-kinase (PI3K) and protein kinase A (PKA) pathways in SKOV-3 ovarian cancer cells (Choi et al. 2006). These results suggest that gonadotropins may play an important, yet not fully understood, role in metastatic spread of ovarian cancer.

Mitogen-activated protein kinases (MAPKs) play a pivotal role in transmitting signals from external stimuli such as hormones, stress and chemotherapeutics to cellular responses including proliferation, differentiation and apoptosis (Yoon \& Seger 2006). Three subgroups of MAPKs have been identified including extracellular signal-regulated kinases (ERKs), p38 and Jun N-terminal kinases/stress-activated protein kinases. MAPK signalling cascades can be activated by both receptor tyrosine kinases, such as the epidermal growth factor receptor (EGFR; Grant et al. 2002) and $\mathrm{G}$ protein-coupled receptors (GPCRs; Goldsmith \& Dhanasekaran 2007). Both FSH and LH signal through their respective GPCRs, FSH receptor (FSHR) and LHR, with the LHR also acting as the receptor for human chorionic gonadotropin (Viswanath et al. 2007). Recently, it has been reported that the MAPK signalling cascade is activated by gonadotropins in immortalised OSE cells (Choi et al. 2002), leading to upregulation of the EGFR (Choi et al. 2005). However, to date, the molecular pathways leading to gonadotropin-induced ERK1/2 activation in EOC have not been described.

The protein kinase $\mathrm{C}$ (PKC) family is a group of serine-threonine kinases, with individual isozymes being involved in a variety of cellular functions, including cell growth, memory, survival, apoptosis, signal transduction, gene expression, migration and hormone action (Dempsey et al. 2000, Koivunen et al. 2006). PKCs can be subdivided into three major groups based on their structural and functional features including conventional isoforms (cPKC; $\alpha, \beta \mathrm{I}, \beta \mathrm{II}$ and $\gamma$ ) that are diacylglycerol (DAG) sensitive and calcium responsive, novel isoforms $(\mathrm{nPKC} ; \delta, \varepsilon, \eta$ and $\theta$ ) that are DAG sensitive but not calcium responsive, and atypical isoforms (aPKCs; $\zeta$ and $\mathrm{t} / \lambda$ in human/mouse) that are neither DAG nor calcium dependent (Parker \& Murray-Rust 2004). The signalling events following activation of PKC are not thoroughly characterised; however, PKC isozymes are known to regulate PI3K, glycogen synthase kinase-3 $\beta$ and MAPK signalling pathways (Ali et al. 2009). PKC $\alpha$ has been specifically implicated in FSH-induced proliferation of the serous subtype EOC cell line HRA (Ohtani et al. 2001).

Here, we show that the gonadotropins LH and FSH activate ERK1/2 signalling in EOC cell lines of the serous and clear cell histopathological subtypes leading to both gonadotropin-induced cell migration and proliferation. Furthermore, we demonstrate that both calcium and PKC $\delta$ are required for gonadotropininduced activation of ERK1/2 and consequent migration and proliferation of EOC cells.

\section{Materials and methods}

\section{Materials}

Human pituitary LH and recombinant FSH were provided by Dr A F Parlow (National Hormone and Pituitary Program, Harbor-University of California-Los Angeles Medical Center, Torrance, CA, USA). PD98059, a MAPK (MEK) inhibitor; forskolin, an activator of adenylyl cyclase; verapamil hydrochloride, an L-type calcium channel blocker; and dantrolene sodium salt, a ryanodine receptor antagonist, were obtained from Sigma-Aldrich Corporation. The general PKC inhibitor GF 109203X was purchased from Invitrogen. Isobutylmethylxanthine (IBMX), a selective inhibitor of calcium-calmodulin-dependent phosphodiesterase, myristoylated PKA inhibitor amide 14-22 (myrPKAi), PKC $\delta$ inhibitor rottlerin and $\mathrm{PKC} \beta$ inhibitor 3-(1-(3-imidazol-1-ylpropyl)-1H-indol-3-yl)-4-anilino1H-pyrrole-2,5-dione were obtained from Calbiochem (San Diego, CA, USA). Antibodies were purchased from the following companies: phosphorylated Thr202/Tyr204 and total p42/p44 MAPK, Cell Signaling,

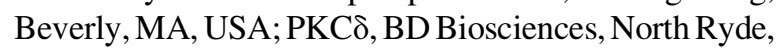
NSW, Australia; $\alpha$-tubulin, Sigma-Aldrich Corporation and GAPDH, Abcam, Cambridge, MA, USA. 


\section{Cell culture and treatments}

OVCAR-3, a human serous EOC cell line, was obtained from the American Type Culture Collection (Manassas, VA, USA), and OV207, a clear cell adenocarcinomaderived cell line, was a kind gift from Drs C Conover and K Kalli (Mayo Clinic, Rochester, MN, USA; Conover et al. 1998). BSA was obtained at different times from Thermo Trace (Melbourne, VIC, Australia) or from Sigma-Aldrich. All cell lines were cultured in RPMI 1640 (Gibco, Invitrogen) supplemented with $10 \%$ FBS (Gibco or SAFC Biosciences, Brooklyn, VIC, Australia) and $0.3 \mathrm{mg} / \mathrm{l}$ glutamine (Gibco) at $37^{\circ} \mathrm{C}$ in $5 \% \mathrm{CO}_{2}$. Cells were plated at a density of $2 \times 10^{5}$ cells per well in six-well tissue culture plates, and were allowed to attach overnight. After attachment, culture medium was changed to serum-free culture medium containing $0.1 \% \mathrm{BSA}$, and after $24 \mathrm{~h}$, cells were treated with $10 \mathrm{nM}$ FSH or $\mathrm{LH}$ and agonists or inhibitors as indicated.

\section{SDS-PAGE and western analysis}

After treatment, cells were washed twice in ice-cold PBS before the addition of cell lysis buffer (62.5 mmol/1 Tris-HCl (pH 6.8), 2\% SDS, $10 \%$ glycerol, $0.01 \%$ bromophenol blue, $1 \mathrm{mM}$ sodium pyrophosphate) containing $10 \%(\mathrm{v} / \mathrm{v})$ protease inhibitor cocktail (Sigma-Aldrich). Cell lysates were sonicated for 2 min (Vibracell, Sonics \& Materials, Newton, CT, USA), and were then heated for $5 \mathrm{~min}$ at $95{ }^{\circ} \mathrm{C}$. Lysates were electrophoresed on $10 \%$ Novex NuPage gels (Invitrogen) at $185 \mathrm{~V}$ for $55 \mathrm{~min}$, and were transferred to a nitrocellulose membrane by a wet transfer system (Bio-Rad) at $100 \mathrm{~V}$ for $90 \mathrm{~min}$. After blocking with $5 \%$ skim milk for $1 \mathrm{~h}$, blots were probed with the primary antibody in $5 \%$ BSA overnight at $4{ }^{\circ} \mathrm{C}$ before incubation with peroxidase-labelled secondary antibody in 5\% skim milk for $1 \mathrm{~h}$ at room temperature. Chemiluminescence was detected with Super Signal ECL reagent (Pierce, Rockford, IL, USA) and visualised using the Fujifilm LAS-3000 imaging system (Berthold Australia Pty Ltd, Bundoora, VIC, Australia), and bands were quantitated using Multi Gauge 3.0 (Fujifilm Australia Pty Ltd, Brookvale, NSW, Australia).

\section{Enzyme immunoassay for intracellular cAMP}

To measure intracellular cAMP, cells were plated at a density of $5 \times 10^{5}$ cells per well in six-well tissue culture plates, allowed to attach overnight and then serum deprived for $24 \mathrm{~h}$. The cells were preincubated in a serum-free medium containing $100 \mu \mathrm{M}$ IBMX for
30 min and were treated with $\mathrm{FSH}, \mathrm{LH}$ or forskolin for $10 \mathrm{~min}$ at the doses indicated. Intracellular cAMP levels were measured using an enzyme immunoassay kit (Cayman Chemical, Ann Arbor, MI, USA). Because intracellular cAMP levels were $<5 \mathrm{pmol} / \mathrm{ml}$, the samples were acetylated as described by the manufacturer, resulting in a detection limit of $0.1 \mathrm{pmol} / \mathrm{ml}$.

\section{Downregulation of PKC $\delta$ by siRNA}

Amaxa Nucleofector Technology (Lonza Cologne AG, Cologne, Germany) was used to transfect cells with a commercial PKC $\delta$ small interfering RNA (siRNA), target sequence: 5'-CAGCAGCAAGTGCAACAT-3' (Qiagen). Subconfluent cells were harvested and diluted to $1 \times 10^{6}$ cells $/ \mathrm{ml}$ with Nucleofector solution T. Up to $200 \mathrm{nM}$ of siRNA were added to $100 \mu \mathrm{l}$ of cell suspension followed by electroporation using program T-016. A non-silencing negative control siRNA, target sequence: 5'-AATTCTCCGAACGTGTCACGT-3' (Qiagen), was used at the same concentration as PKC $\delta$ siRNA for all the experiments. RNA was extracted using TRIZOL and reverse transcribed using Superscript III reverse transcriptase according to the manufacturer's instructions (Invitrogen).

Quantitative RT-PCR was performed in triplicate using a TaqMan Gene Expression Assay ( $P K C \delta$ : Hs00178914_m1; Applied Biosystems, Foster City, CA, USA) and TaqMan Universal PCR Master Mix, No AmpErase UNG (Applied Biosystems) on a RotorGene 3000 (Corbett Research, Mortlake, NSW, Australia). Reagents were aliquoted using the epMotion 5070 automated pipetting system (Eppendorf, Hamburg, Germany). The endogenous reference gene used for normalisation was hydroxymethylbilane synthase (HMBS) (Hs00609297_m1), and results are expressed as $P K C \delta: H M B S$.

\section{Cell proliferation assay}

For proliferation analysis, $1.5-2 \times 10^{4}$ cells were seeded in 48-well plates, and $10 \mathrm{nM} \mathrm{FSH,} 10 \mathrm{nM} \mathrm{LH}$ and/or inhibitors (10 $\mu \mathrm{M}$ PD98059, $25 \mu \mathrm{M}$ verapamil or $100 \mathrm{nM}$ GF 109230X) were added in $10 \%$ FBScontaining medium. After 3 days, media were changed, and fresh gonadotropins and/or inhibitors were added. After 7 days, cells were trypsinised and resuspended in $10 \%$ FBS-containing medium, and the cell number was determined using a haemocytometer. Three outside squares were counted for each well, and each condition was analysed in triplicate. 


\section{Monolayer wound closure migration assay}

For monolayer wounding assays, OV207 cells were plated at a density of $1 \times 10^{5}$ cells per well in 24-well tissue culture plates, and were allowed to attach overnight. Confluent monolayers were scratched using a $10-\mu$ pipette tip and washed once with serum-free medium. Fresh medium containing 10\% FBS and inhibitors (10 $\mu \mathrm{M}$ PD98059, $25 \mu \mathrm{M}$ verapamil, $100 \mathrm{nM}$ GF $109230 \mathrm{X}$ or $3 \mu \mathrm{M}$ rottlerin) plus or minus $10 \mathrm{nM}$ FSH or LH was added. Additionally, $10 \mu \mathrm{M}$ cytosine $\beta$-D-arabinofuranoside (Sigma-Aldrich), an inhibitor of DNA synthesis, was included in all wells to exclude any possible proliferation effects. After $22 \mathrm{~h}$, migration was assessed by phase contrast microscopy, documented by digital photography and quantitated using Multi Gauge V3.0 software (Fujifilm). Migration was calculated as the initial wounded (i.e. cell-free) area minus the final cell-free area after migration, and is reported relative to the migration of untreated control cells expressed as 1.0.

\section{Transwell migration assay}

Uncoated cell culture inserts (24-well, pore size $8 \mu \mathrm{m}$; BD Biosciences) were seeded with either $2.5 \times 10^{4}$ (OV207) or $1.5 \times 10^{5}$ (OVCAR-3) cells in $100 \mu \mathrm{l}$ of medium containing $0.1 \%$ FBS and inhibitors. OV207 cells were pretreated with inhibitors $(10 \mu \mathrm{M}$ PD98059 or $100 \mathrm{nM} \mathrm{GF} 109230 \mathrm{X}$ ) for $30 \mathrm{~min}$. OVCAR-3 cells were additionally treated with either $25 \mu \mathrm{M}$ verapamil or $3 \mu \mathrm{M}$ rottlerin in a similar fashion. Inhibitors did not show any toxicity to the cells over the course of these assays. FSH or LH, $10 \mathrm{nM}$, was added to the top chamber. Medium containing 10\% FBS, inhibitors and $10 \mu \mathrm{M}$ cytosine $\beta$-D-arabinofuranoside was added to the lower chamber, and it served as a chemotactic agent. After $22 \mathrm{~h} \mathrm{(OV207)}$ or $48 \mathrm{~h}$ (OVCAR-3), non-migrating cells were wiped from the upper side of the membrane with a cotton swab, and cells on the lower side were washed in PBS, fixed in cold methanol $\left(-20{ }^{\circ} \mathrm{C}\right)$ for $20 \mathrm{~min}$ and air dried. Membranes were excised and mounted on glass slides with ProLong Gold Antifade containing 4',6-diamidino-2-phenylindole, dihydrochloride (Invitrogen) for visualisation of the nuclei. Nuclei were counted using an epifluorescent microscope equipped with a digital camera (Olympus distrene-plasticiser-xylene-71). Each individual experiment had duplicate inserts, and five microscopic fields $(\times 200$ magnification for OV207 and $\times 400$ magnification for OVCAR-3) were counted per insert.

\section{Statistical analysis}

Data analysis was performed using SPSS software 16.0 (SPSS Australasia Pty Ltd, Chatswood, NSW, Australia), and results are represented as the mean \pm s.E.M. from at least three independent experiments. Statistical significance was determined by ANOVA with Fisher's least significant difference post hoc test. $P<0.05$ was considered statistically significant.

\section{Results}

\section{Gonadotropins activate the MAPK/ERK1/2 signalling pathway in EOC cells}

OVCAR-3 cells have previously been shown to express the FSHR (Choi et al. 2002, Zhang et al. 2009). To confirm the expression of both FSHR and LHR, OV207 and OVCAR-3 cells were subjected to immunofluorescent staining (Supplementary Figure 1A and $\mathrm{B}$, see section on supplementary data given at the end of this article), which clearly indicated the presence of both receptors in both cell types. To determine the effects of gonadotropins on ERK1/2 signalling in OV207 and OVCAR-3 EOC cells, cell lines were treated with $10 \mathrm{nM}$ FSH or LH over 5-60 min. Both FSH and LH induced an increase in phosphorylated ERK1/2 in both cell lines with maximal stimulation between 5 and $10 \mathrm{~min}$ (Fig. 1A). Pretreatment of cells with PD98059 for 30 min abolished gonadotropin-induced ERK1/2 activation, which was measured after treatment with FSH or LH for $10 \mathrm{~min}$ (Fig. 1B and C).

\section{CAMP and PKA are not involved in gonadotropin-induced ERK1/2 activation}

Gonadotropins are known to signal through their GPCRs, typically stimulating adenylyl cyclase activity leading to increased cAMP formation and activation of PKA. We therefore determined whether this was the mechanism of gonadotropin-induced ERK1/2 activation in OV207 and OVCAR-3 cells. cAMP levels were determined in OV207 and OVCAR-3 cells after treatment with either $10 \mathrm{nM}$ FSH or LH. No change in cAMP levels was observed after up to 15 min exposure to either gonadotropin (data not shown). To stabilise intracellular cAMP levels, OV207 and OVCAR-3 cells were pretreated with $100 \mu \mathrm{M}$ IBMX for $30 \mathrm{~min}$ followed by treatment with either 10 or $100 \mathrm{nM} \mathrm{FSH}$ or LH for $10 \mathrm{~min}$. Treatment with IBMX alone significantly increased basal intracellular cAMP in OVCAR-3 cells; however, additional treatment with either gonadotropin did not increase cAMP levels 

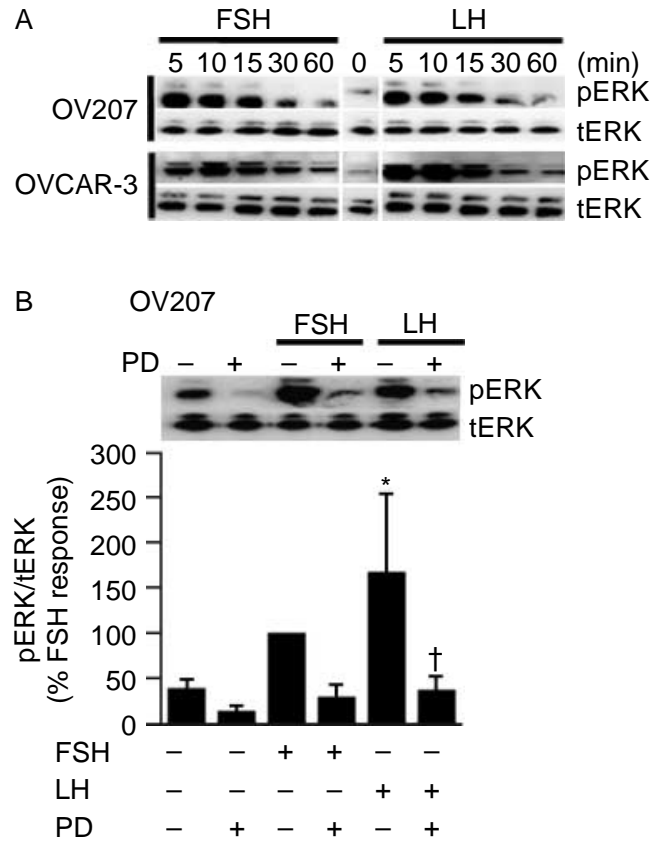

C OVCAR-3

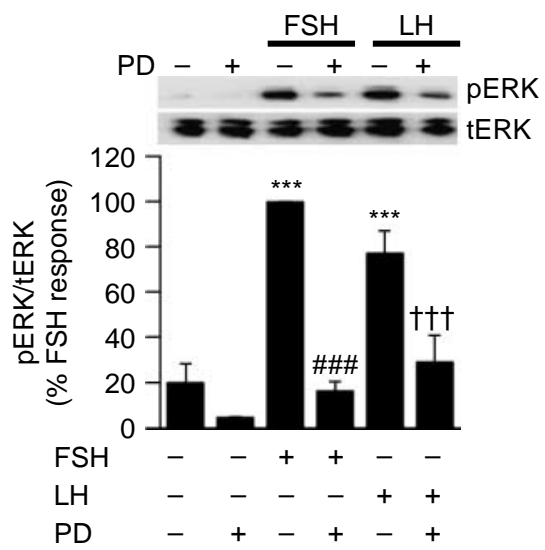

Figure $1 \mathrm{FSH}$ and $\mathrm{LH}$ induce ERK1/2 phosphorylation in ovarian cancer cells. (A) OV207 and OVCAR-3 cells were serum deprived for $24 \mathrm{~h}$ and treated in a time-dependent manner with $10 \mathrm{nM}$ FSH or $\mathrm{LH}$, and cell lysates were immunoblotted for phosphorylated ERK1/2 (pERK) and total ERK1/2 (tERK). (B) OV207 or (C) OVCAR-3 cells were pretreated with $10 \mu \mathrm{M}$ PD98059 (PD) for $30 \mathrm{~min}$, followed by treatment with $10 \mathrm{nM}$ FSH or LH for $10 \mathrm{~min}$, and cell lysates were immunoblotted for $p E R K 1 / 2$ and tERK1/2. Data are expressed as $p E R K 1 / 2$ relative to tERK $1 / 2$ ( $p E R K / t E R K$ ). All blots are representative of at least three independent experiments. Graphs represent pooled data expressed as mean percentage of FSH response \pm S.E.M. of three individual experiments. ${ }^{*} P<0.05$ versus untreated control; ${ }^{* *} P<0.001$ versus untreated control; \#\#\# $P<0.001$ versus FSH alone; ${ }^{\dagger} P<0.05$ versus $\mathrm{LH}$ alone; ${ }^{{ }^{\dagger \dagger}} P<0.001$ versus $\mathrm{LH}$ alone (by ANOVA). further (Fig. 2A). cAMP levels were unchanged by either IBMX or gonadotropins in OV207 cells (Fig. 2B). In contrast, increasing concentrations of forskolin led to a dose-dependent increase in intracellular cAMP in both cell lines, with OVCAR-3 cells showing the highest levels of forskolin-induced cAMP (Fig. 2C), confirming that the adenylyl cyclase system was functional in these cell lines. To further exclude the involvement of the PKA pathway in gonadotropininduced ERK1/2 phosphorylation, cells were pretreated with a myrPKAi, a highly specific inhibitor of PKA, followed by treatment with either FSH or LH for 10 min. Both FSH and LH increased phosphorylation of ERK1/2 in the presence of myrPKAi, confirming that PKA is not involved in gonadotropin-induced ERK1/2 phosphorylation (Fig. 2D).

\section{Calcium plays an important role in gonadotropin-induced ERK1/2 activation}

Since cAMP was not involved in gonadotropininduced ERK1/2 activation in the cell lines analysed, we explored the role of calcium as a possible second messenger in this signalling pathway. Sequestration of extracellular calcium by the chelating agent EGTA significantly reduced gonadotropin-induced phosphorylation of ERK1/2 in OV207 and OVCAR-3 cells, suggesting that calcium influx is required for gonadotropin-induced ERK1/2 activation (Fig. 3A and $\mathrm{B}$ ). Furthermore, treatment with $25 \mu \mathrm{M}$ verapamil for $30 \mathrm{~min}$ significantly inhibited gonadotropininduced ERK1/2 activation (Fig. 3A and B).

We then sought to determine whether intracellular release of calcium plays a role in gonadotropininduced ERK1/2 activation. Cells were treated with dantrolene, a ryanodine receptor antagonist which blocks the release of calcium from intracellular calcium stores. Dantrolene significantly inhibited gonadotropin-induced ERK1/2 phosphorylation in both cell lines (Fig. 3C and D). Taken together, these results show that gonadotropin-induced ERK1/2 activation is dependent on intracellular calcium, and both intracellular calcium release and calcium influx through L-type voltage-dependent calcium channels need to be active to maintain responsiveness to gonadotropins in EOC cells.

\section{PKC $\delta$ mediates gonadotropin-induced ERK1/2 activation}

Given the role demonstrated for calcium, but not for PKA, in gonadotropin-induced ERK1/2 activation, we examined a possible role for PKC. Gonadotropininduced phosphorylation of ERK1/2 was reversed 

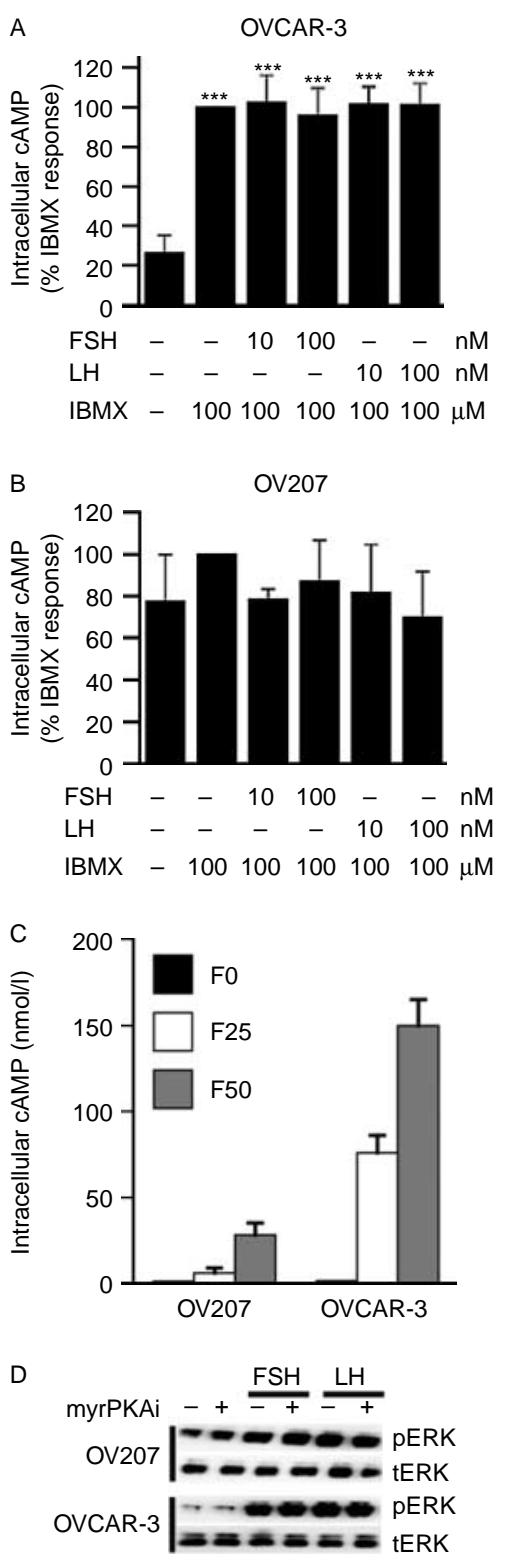

Figure 2 The PKA pathway does not have a role in gonadotropin-induced ERK1/2 phosphorylation in OVCAR-3 and OV207 cells. (A) OVCAR-3 and (B) OV207 cells were serum deprived for $24 \mathrm{~h}$, pretreated with $100 \mu \mathrm{M}$ IBMX for $30 \mathrm{~min}$, and then treated with either 10 or $100 \mathrm{nM}$ of $\mathrm{FSH}$ or $\mathrm{LH}$ for $10 \mathrm{~min}$. Data are the mean \pm S.E.M. of three independent experiments normalised to IBMX treatment alone (OVCAR-3, $3.95 \pm 2.95 \mathrm{nmol} / \mathrm{l} \mathrm{cAMP}$; OV207, $1.08 \pm 0.2 \mathrm{nmol} / \mathrm{l} \mathrm{cAMP)}$. ${ }^{* * *} P<0.001$ versus untreated control (by ANOVA). (C) OV207 and OVCAR-3 cells were serum deprived for $24 \mathrm{~h}$, and were then treated for $10 \mathrm{~min}$ with increasing concentrations of forskolin $-0 \mu \mathrm{M}$ (F0), $25 \mu \mathrm{M}$ (F25) or $50 \mu \mathrm{M}$ (F50). Intracellular cAMP is shown as the mean of two independent experiments \pm S.D. (D) Serum-deprived cells were pretreated with $1 \mu \mathrm{M}$ myristoylated PKA inhibitor amide 14-22 (myrPKAi) for $30 \mathrm{~min}$ followed by treatment with $10 \mathrm{nM} \mathrm{FSH}$ or LH for $10 \mathrm{~min}$. Cell lysates were subjected to immunoblotting for $p E R K 1 / 2$ (pERK) and tERK1/2 (tERK). Blots are representative of three independent experiments. by the PKC inhibitor GF 109203X (Fig. 4). Since GF 109203X has been shown to efficiently inhibit the PKC isoforms $\alpha, \beta, \delta$ and $\varepsilon$ at nanomolar concentrations in rat brain (Martiny-Baron et al. 1993) and PKC $\theta$ in transiently transfected COS-1 cells (Uberall et al. 1997), these data support the involvement of one of these PKC isoforms in gonadotropin-induced ERK1/2 activation.

As calcium is involved in gonadotropin-induced activation of ERK1/2, we examined the possible involvement of calcium-dependent PKC isozymes. PKC $\alpha$ and $\mathrm{PKC} \beta$, but not $\mathrm{PKC} \gamma$, were detected by western blot analysis in both cell lines (data not shown). siRNA-mediated knockdown of PKC $\alpha$ showed no effects on activation of ERK1/2 in OV207 cells and variable effects on ERK1/2 phosphorylation in OVCAR-3 cells treated with either FSH or LH (Supplementary Figure 2A, see section on supplementary data given at the end of this article and data not shown). Treatment of OVCAR-3 cells with a specific PKC $\beta$ inhibitor significantly inhibited FSH-induced phosphorylation of ERK1/2 but not LH-stimulated ERK1/2 activation (Supplementary Figure 2B), whereas in OV207 cells, the PKC $\beta$ inhibitor did not inhibit FSH- or LH-induced phosphorylation of ERK1/2 (Supplementary Figure 2C), and it showed no effect on gonadotropin-induced migration (Supplementary Figure 2D).

To further investigate which PKC isoform mediates gonadotropin-induced ERK1/2 activation, cells were treated with rottlerin, a specific PKC $\delta$ inhibitor, at low $(3 \mu \mathrm{M})$ concentrations. Treatment with rottlerin reduced gonadotropin-induced ERK1/2 activation in OV207 and OVCAR-3 cell lines (Fig. 5A and B). Similarly, downregulation of PKC $\delta$ with siRNA, achieving almost $80 \%$ reduction in mRNA up to $72 \mathrm{~h}$ (Fig. 5C), significantly inhibited gonadotropin-induced ERK1/2 activation (Fig. 5D and E). Downregulation of PKC $\delta$ by specific siRNA did not affect $\mathrm{PKC} \alpha$ protein levels (Fig. 5D), with these two PKC isoforms being known to act coordinately, often with opposing effects (Deucher et al. 2002).

\section{Gonadotropin-induced migration of EOC cells is dependent on ERK1/2 activation regulated by calcium and $\operatorname{PKC} \delta$}

Treatment of OV207 and OVCAR-3 cells with $10 \mathrm{nM}$ FSH or LH significantly increased cell migration in comparison to untreated control cells (Fig. 6). PD 98059 and GF 109230X significantly inhibited basal and gonadotropin-induced migration in OV207 cells in the monolayer scratch wound 
A

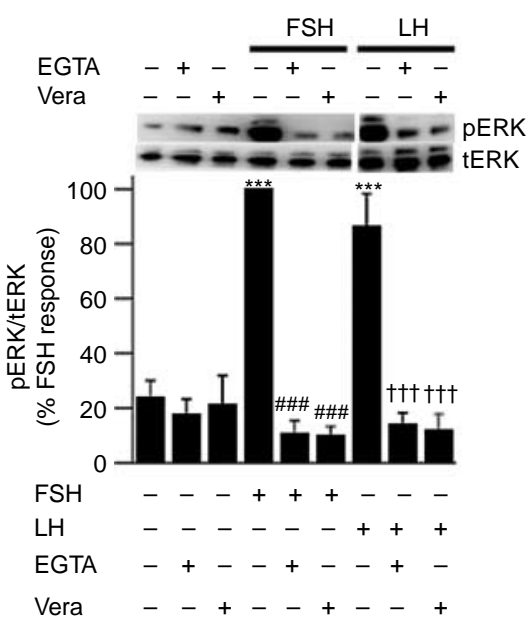

C

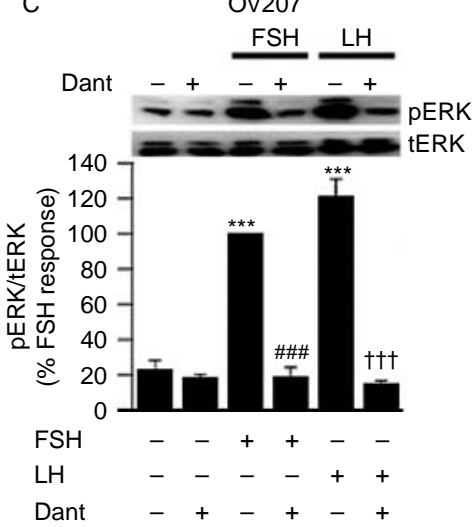

B

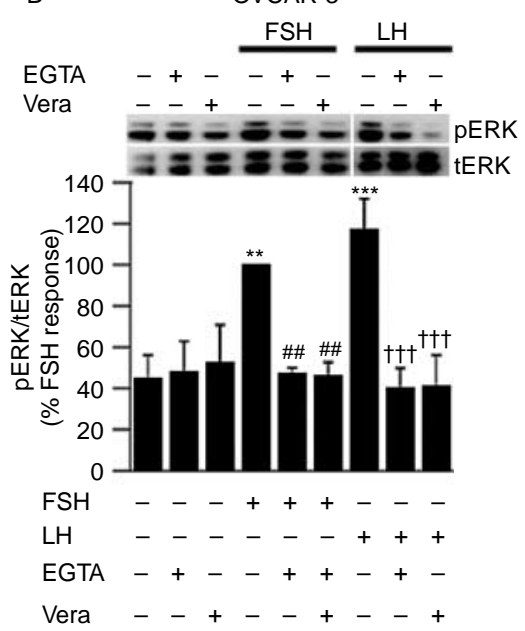

D

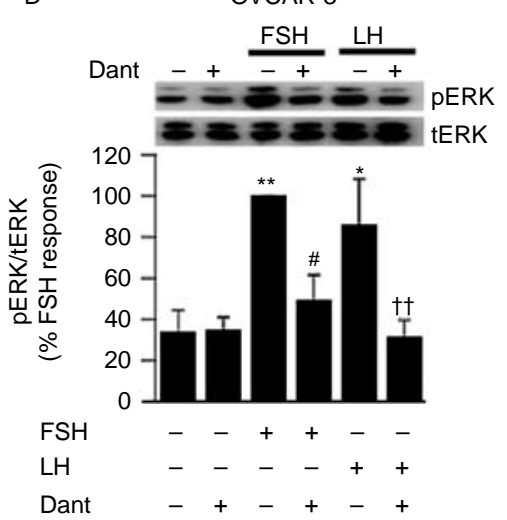

Figure 3 Calcium is required for gonadotropin-induced ERK1/2 phosphorylation. Serum-deprived (A) OV207 or (B) OVCAR-3 cells were pretreated with $3 \mathrm{mM}$ EGTA or $25 \mu \mathrm{M}$ verapamil (Vera) for 30 min followed by 10 min of treatment with $10 \mathrm{nM}$ FSH or LH. ${ }^{\star *} P<0.01$ versus untreated control; ${ }^{* \star} P<0.001$ versus untreated control; ${ }^{\# \#} P<0.01$ versus $\mathrm{FSH}$ alone; ${ }^{\# \# \#} P<0.001$ versus FSH alone; ${ }^{\dagger+} P<0.001$ versus LH alone (by ANOVA). (C) Serum-deprived OV207 or (D) OVCAR-3 cells were pretreated with $25 \mu \mathrm{M}$ dantrolene (Dant) for 30 min followed by treatment with either $10 \mathrm{nM} \mathrm{FSH}$ or LH. ${ }^{\star} P<0.05$ versus untreated control; ${ }^{\star \star} P<0.01$ versus untreated control; ${ }^{\star \star \star} P<0.001$ versus untreated control; ${ }^{\#} P<0.05$ versus $\mathrm{FSH}$ alone; ${ }^{\# \# \#} P<0.001$ versus FSH alone; ${ }^{+\dagger} P<0.01$ versus LH alone; ${ }^{{ }^{+\dagger}} P<0.001$ versus LH alone (by ANOVA). All cell lysates were subjected to immunoblotting for pERK1/2 (pERK) and tERK1/2 (tERK), and data are expressed as pERK1/2 relative to tERK1/2 (pERK/tERK). All blots are representative of at least three independent experiments. All graphs represent pooled data expressed as mean percentage of FSH response \pm S.E.M. of three individual experiments.

assay (Fig. 6A and B). In OV207 transwell migration assays, LH-induced migration was significantly inhibited by both PD98059 and GF 109230X, with FSH-induced migration showing a reduced trend in cells treated with these inhibitors (Fig. 6C). Transwell migration assays of OVCAR-3 cells showed inhibition of basal and gonadotropin-induced migration with PD98059 and GF 109230X (Fig. 6D), demonstrating that activated ERK1/2 signalling and PKC signalling are required for gonadotropininduced cell migration. Gonadotropin-induced cell migration was also inhibited by treatment with verapamil in both cell lines, indicating a significant role for calcium in this process (Fig. 6B and D). Furthermore, in both cell lines, rottlerin significantly inhibited gonadotropin-induced cell migration (Fig. 6B and D), suggesting that $\mathrm{PKC} \delta$-mediated signalling is important in gonadotropin-induced EOC cell migration.

\section{Gonadotropin-induced proliferation of EOC cells is dependent on ERK $1 / 2$ activation regulated by calcium and $\mathrm{PKC} \delta$}

Treatment of OV207 or OVCAR-3 cells with $10 \mathrm{nM}$ FSH or LH significantly increased cell proliferation in comparison to untreated control cells (Fig. 7A and B). 
A

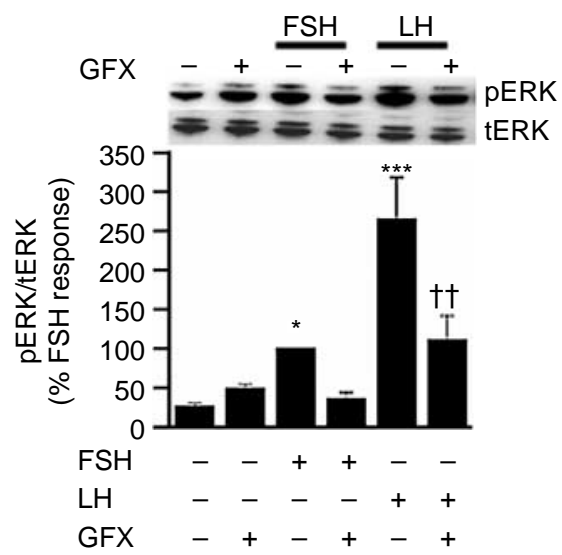

B

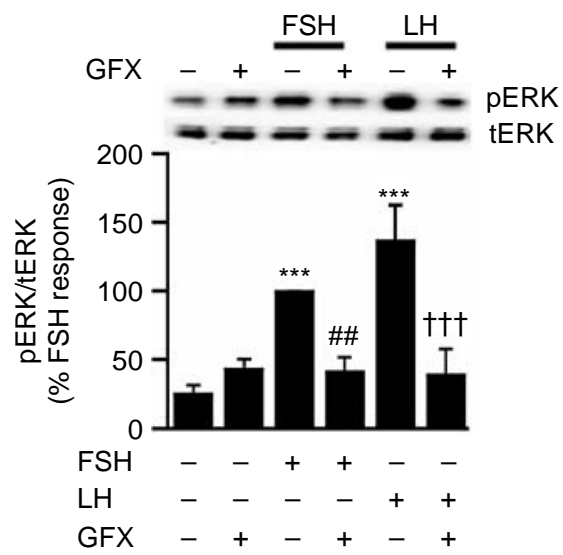

Figure $4 \mathrm{PKC}$ has a role in gonadotropin-induced ERK1/2 phosphorylation. Serum-deprived (A) OV207 or (B) OVCAR-3 cells were pretreated with $100 \mathrm{nM}$ GF $109203 \mathrm{X}$ (GFX) for $30 \mathrm{~min}$ followed by treatment with $10 \mathrm{nM} \mathrm{FSH}$ or $\mathrm{LH}$. Cell lysates were immunoblotted for $p E R K 1 / 2$ and tERK $1 / 2$, and data are expressed as $\mathrm{pERK} / \mathrm{tERK}$. Data in graphs were pooled and expressed as mean percentage of $\mathrm{FSH}$ response \pm S.E.M. of three individual experiments. ${ }^{*} P<0.05$ versus untreated control; ${ }^{* \star \star} P<0.001$ versus untreated control; ${ }^{\# \#} P<0.01$ versus FSH alone; ${ }^{{ }^{\dagger \dagger}} P<0.01$ versus $\mathrm{LH}$ alone; ${ }^{{ }^{t \dagger}} P<0.001$ versus $\mathrm{LH}$ alone (by ANOVA).

Proliferation was inhibited by PD98059 (Fig. 7A and B), demonstrating that activated ERK1/2 signalling is required for gonadotropin-induced cell proliferation. Gonadotropin-induced cell proliferation was also inhibited by treatment with verapamil, indicating that calcium influx is required in this process (Fig. 7A and B), and by GF 109203X (Fig. 7A and B), indicating that $\mathrm{PKC}$ is involved. Downregulation of PKC $\delta$ by siRNA in OVCAR-3 cells reduced both FSH- and LH-induced (Fig. 7C and D) proliferation in OVCAR-3 cells, demonstrating that $\mathrm{PKC} \delta$ plays an important role in gonadotropin-induced EOC proliferation.

\section{Discussion}

Strong epidemiological evidence, largely gathered through studies of postmenopausal women, suggests that elevated levels of serum gonadotropins FSH and LH may have a role in malignant transformation of OSE cells. We have shown that gonadotropin-induced activation of ERK1/2 relies on both calcium- and PKC $\delta$-dependent mechanisms in two EOC cell lines representing the serous and clear cell subtypes. While other in vitro studies have shown that gonadotropins induce proliferation in normal and immortalised OSE cells, as well as in EOC cell lines (Wimalasena et al. 1992, Parrott et al. 2001, Syed et al. 2001, Ji et al. 2004), little is known about gonadotropin involvement in other aspects of ovarian tumourigenesis such as migration. We have shown that gonadotropin-induced ERK1/2 activation is required for EOC cell migration and proliferation, and that these effects are regulated by both calcium and PKC $\delta$.

The GPCRs for FSH and LH are known to be expressed in both normal OSE cells and EOC cells (Parrott et al. 2001, Choi et al. 2002, Gebauer et al. 2004, Ji et al. 2004). Treatment with FSH has been shown to activate the MAPK signalling cascade as indicated by phosphorylation of ERK1/2 in tumourigenic and immortalised normal OSE cells (Choi et al. 2002). LH has also been shown to activate ERK $1 / 2$ in a non-tumourigenic OSE cell line (Choi et al. 2005). However, to date, the molecular pathways leading to gonadotropin-induced ERK1/2 activation in EOC have not been described.

In ovarian granulosa cells, the cells of origin of a small percentage of ovarian tumours, gonadotropins signal by activating the stimulatory G-protein $\left(\mathrm{G}_{\mathrm{s}}\right)$ of their respective GPCR. The $\alpha$-subunit of a $\mathrm{G}_{\mathrm{s}}$ protein $(\mathrm{G} \alpha \mathrm{S})$ stimulates adenylyl cyclase activity causing increased production of cAMP leading to activation of PKA (Hsueh et al. 1984, Cotton \& Claing 2009). This accepted model of signalling through gonadotropin receptors is not true for FSH and LH in all EOCs, given that both gonadotropins failed to increase intracellular cAMP in the cell lines studied. These findings are consistent with data reported by Choi et al. (2002) who demonstrated no increase in basal cAMP after FSH treatment in a non-tumourigenic immortalised cell line (IOSE-29) and its tumourigenic derivative (IOSE-29EC) after up to 60 min incubation, but saw induction of cAMP in human granulosa cells under the same conditions. However, total cAMP levels have been shown to increase up to 1.4 -fold in response to incubation with $\mathrm{LH}$ for $60 \mathrm{~min}$ in the EOC cell line HEY (Slot et al. 2006). Additionally, it has been shown 
A

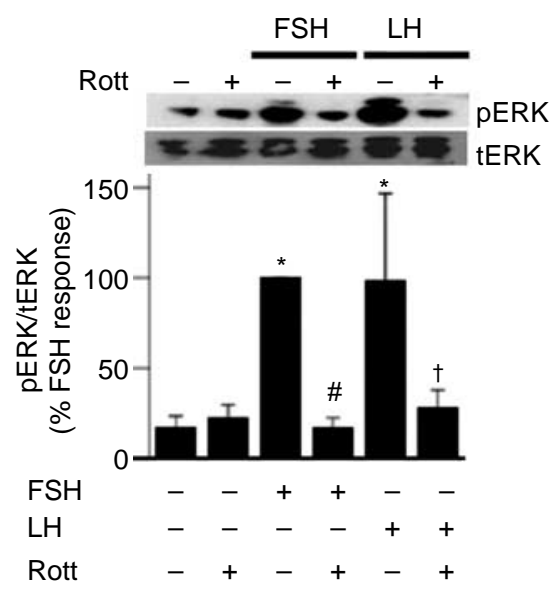

B

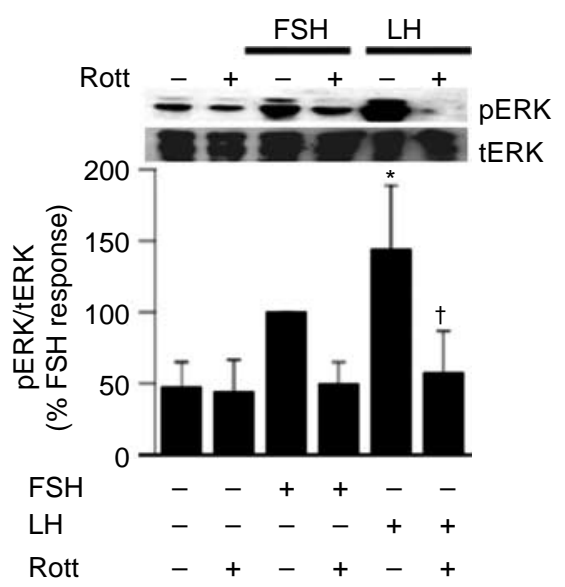

C

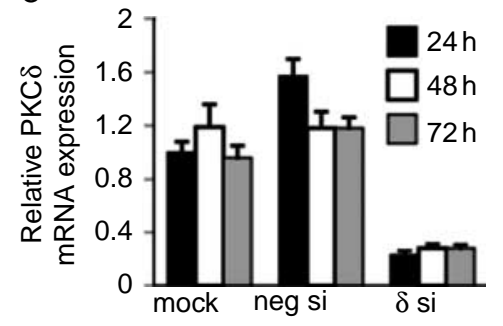

D

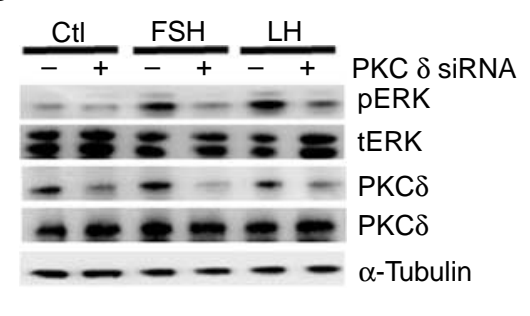

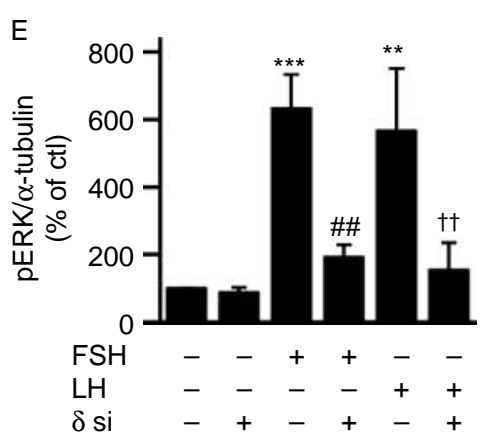

Figure 5 PKC $\delta$ mediates gonadotropin-induced ERK1/2 phosphorylation. Serum-deprived (A) OV207 or (B) OVCAR-3 cells were pretreated with $3 \mu \mathrm{M}$ rottlerin (Rott) followed by 10 min of treatment with $10 \mathrm{nM} \mathrm{FSH}$ or LH. Cell lysates were immunoblotted for pERK $1 / 2$ and tERK1/2, and data are expressed as pERK/tERK. Data in graphs were pooled and expressed as mean percentage of FSH response \pm S.E.M. of three individual experiments. ${ }^{\star} P<0.05$ versus untreated $c t$; ${ }^{\#} P<0.05$ versus $\mathrm{FSH}$ alone; ${ }^{\dagger} P<0.05$ versus LH alone (by ANOVA). (C) OVCAR-3 cells were transfected in the following manner: no siRNA (mock), non-silencing negative siRNA (neg si) or PKC $\delta$-specific siRNA ( $\delta \mathrm{si})$. RNA was extracted after 24,48 and $72 \mathrm{~h}$, and quantitative real-time PCR was performed. Relative levels of PKC $\delta$ mRNA normalised to the reference gene HMBS and expressed relative to mock transfected cells are shown. (D) OVCAR-3 cells were transfected with either PKC $\delta$ siRNA (+) or non-silencing negative siRNA (-). After $48 \mathrm{~h}$, cells were treated with $10 \mathrm{nM}$ FSH or $\mathrm{LH}$, and cell lysates were immunoblotted for pERK1/2, tERK1/2, PKC $\delta, \operatorname{PKC} \alpha$ and $\alpha$-tubulin expression.

(E) $p E R K / \alpha$-tubulin ratios were pooled and expressed as mean percentage of untreated control (ctl) cells \pm S.E.M. of three individual experiments performed in duplicate. ${ }^{\star \star} P<0.01$ versus untreated ctl; ${ }^{\star \star \star} P<0.001$ versus untreated ctl; ${ }^{\# \#} P<0.01$ versus FSH alone; ${ }^{\mathrm{t}} P<0.01$ versus $\mathrm{LH}$ alone (by ANOVA).

that gonadotropins slightly elevate intracellular cAMP levels in a number of immortalised OSE cell lines (IOSE-80, IOSE-120 and IOSE-80PC) at earlier time points of between 5 and $15 \mathrm{~min}$ post gonadotropin treatment (Choi et al. 2009). Furthermore, inhibiting PKA in normal and malignant OSE cells for 5 days has been shown to reduce gonadotropin-induced cell proliferation (Syed et al. 2001). Given that a highly specific inhibitor of PKA did not affect gonadotropininduced induction of ERK1/2 phosphorylation in the EOC lines in this study, coupled with the fact that gonadotropins did not increase cAMP in these cells, we conclude that gonadotropin-induced ERK1/2 phosphorylation occurs in a cAMP/PKA-independent manner in OVCAR-3 and OV207 cells.
Intracellular calcium plays a pivotal role in cellular function by regulating activities such as cell division and differentiation, and it is a common intermediate between ERK1/2 and GPCRs (Roderick \& Cook 2008). A rise in intracellular calcium concentration may occur from two different sources: release of calcium from intracellular stores in the endoplasmic reticulum and/or calcium influx via calcium channels from the extracellular space. Calcium levels are important for signalling and growth in OSE cells, with increased proliferation being seen in response to elevated calcium in vitro (McNeil et al. 1998, Hobson et al. 2000, 2003, Bilderback et al. 2002, Wright et al. 2002). This effect has been shown to be mediated by ERK1/2 (Hobson et al. 2000), PI3K 
A
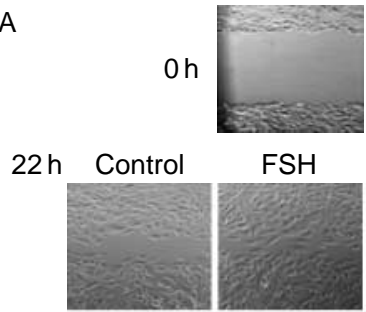

FSH
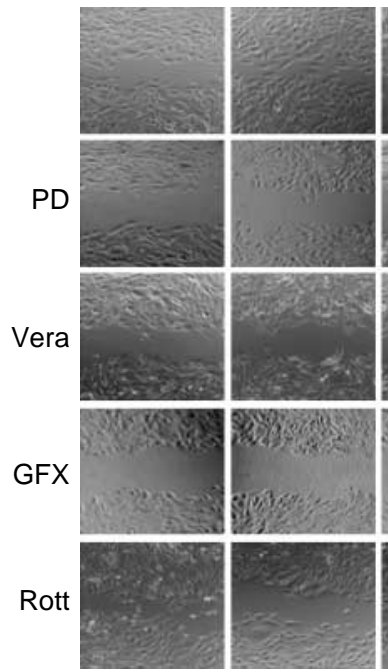

C

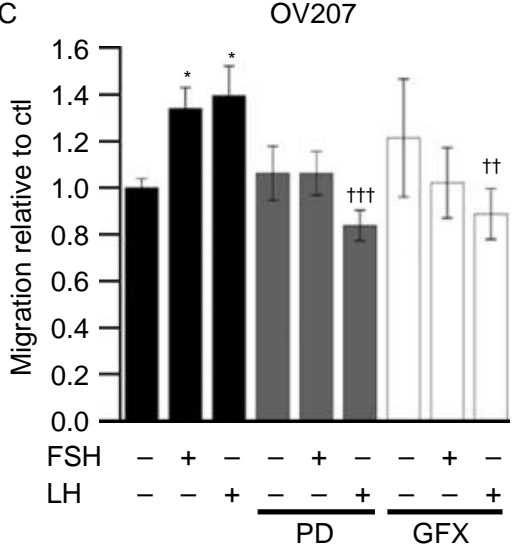

B

OV207
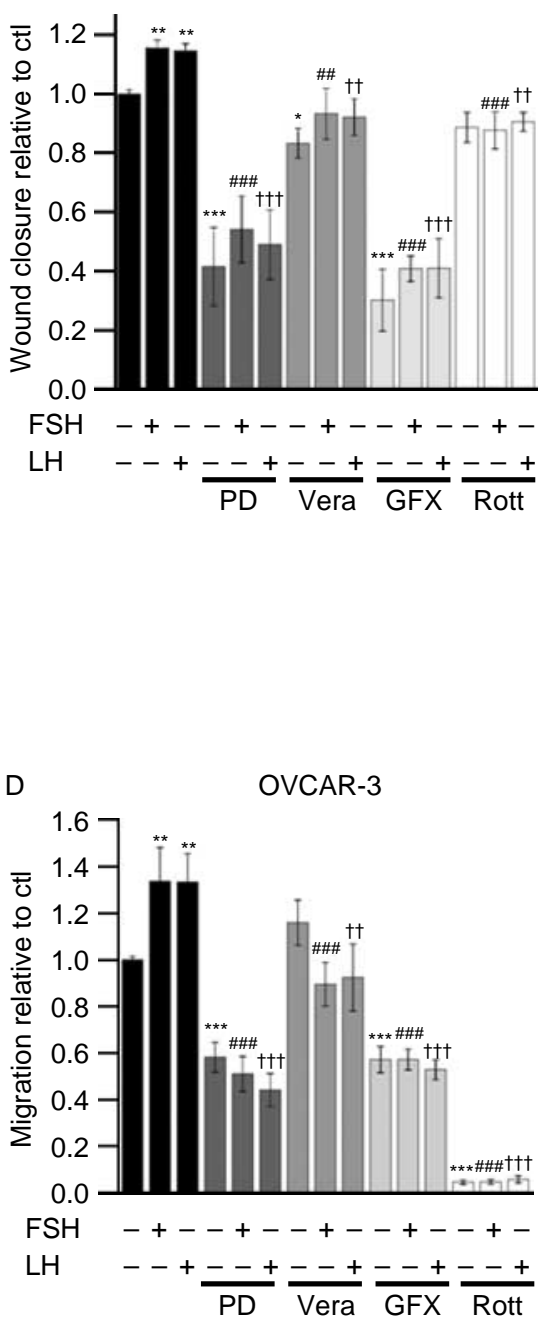

Figure $6 \mathrm{FSH}$ - and LH-induced migration requires activation of MAPK signalling and is regulated by calcium and PKC $\delta$. (A) Confluent OV207 cells were wounded, and then treated with $10 \mathrm{nM} \mathrm{FSH}$ or LH in the presence of either PD98059 (PD, $10 \mu \mathrm{M})$, verapamil (Vera, $25 \mu \mathrm{M}$ ), GF109203X (GFX, $100 \mathrm{nM}$ ) or rottlerin (Rott, $3 \mu \mathrm{M}$ ) for $22 \mathrm{~h}$. Representative photomicrographs are shown at 0 and $22 \mathrm{~h}$ post treatment. (B) Scratch wound closure is expressed as closure relative to that of untreated control (ctl) cells for all experiments. Data are pooled mean \pm S.E.M. from three individual experiments performed in duplicate. (C) OV207 and (D) OVCAR-3 cells were seeded into transwell chambers and treated with either $10 \mathrm{nM} \mathrm{FSH}$ or LH in the presence of PD98059 (PD, $10 \mu \mathrm{M})$, GF 109203X (GFX, $100 \mathrm{nM}$ ), verapamil (Vera, $25 \mu \mathrm{M}$ ) or rottlerin (Rott, $3 \mu \mathrm{M})$. Following incubation for $22-48 \mathrm{~h}$, migration was assessed by staining and counting the nuclei of the cells on the underside of the membrane. Data are pooled mean \pm S.E.M. from three individual experiments performed in duplicate. ${ }^{\star} P<0.05$ versus untreated $\mathrm{ctl} ;{ }^{* \star} P<0.01$ versus untreated $\mathrm{ctl} ;{ }^{* \star \star} P<0.001$ versus untreated ctl; ${ }^{\# \#} P<0.01$ versus $\mathrm{FSH}$ alone; ${ }^{\# \#} P<0.001$ versus $\mathrm{FSH}$ alone; ${ }^{\dagger \dagger} P<0.01$ versus $\mathrm{LH}$ alone; ${ }^{\mathrm{t}+\mathrm{P}} P<0.001$ versus LH alone (by ANOVA).

(Bilderback et al. 2002) and the calcium-sensing receptor $\mathrm{CaR}$ (Hobson et al. 2003). We have shown that FSH- and LH-induced ERK1/2 activation in EOC cell lines is dependent on both extra- and intracellular calcium. Furthermore, our data suggest that gonadotropin-induced ERK1/2 activation is mediated by calcium influx through L-type voltagedependent calcium channels. The mechanism by which gonadotropins evoke calcium influx through these channels is unknown. Touyz et al. (2000) have found that the growth factor type I receptor FSHR, a splicing variant of the FSHR, is able to evoke calcium influx in response to its ligand FSH via L-type voltagedependent calcium channels in transfected HEK293 cells. Additionally, granulosa cells transfected with the ovine growth factor type I receptor FSHR showed 
cAMP-independent activation of the ERK1/2 signalling cascade upon FSH stimulation, which could be abolished by treatment with the intracellular calcium chelator BAPTA/AM or EGTA (Babu et al. 2000), demonstrating dependence on extra- and
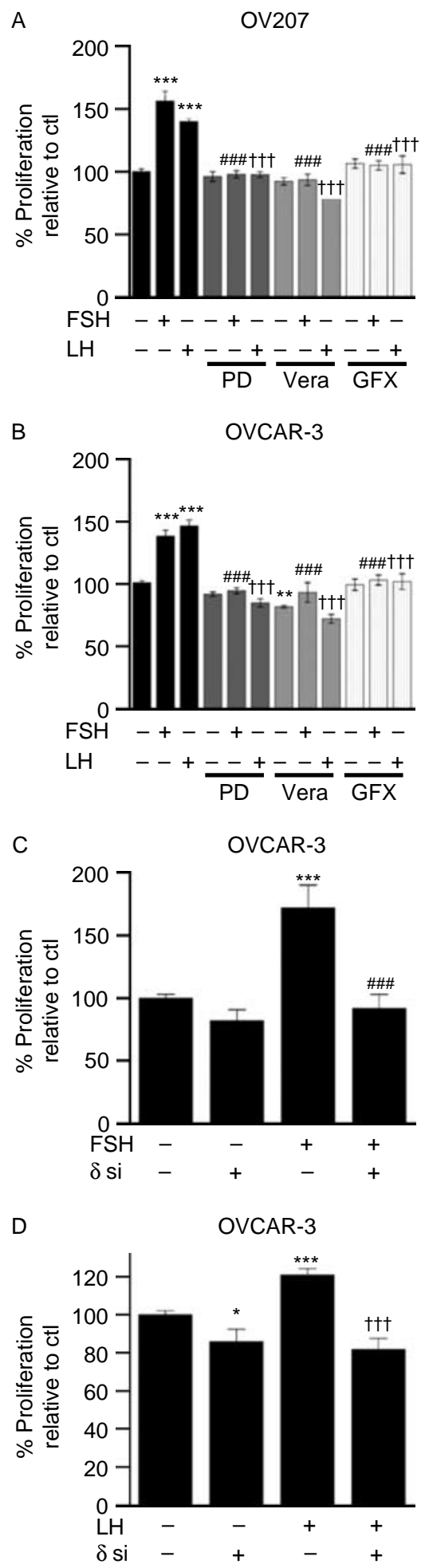

intracellular calcium for activation of ERK1/2 signalling. Our data also support calcium-dependent but cAMP/PKA-independent gonadotropin-induced activation of ERK1/2 signalling in EOC.

We have shown that calcium is a key regulator of gonadotropin-induced EOC cell migration and proliferation via activation of ERK1/2. In particular, verapamil decreased FSH- and LH-induced migration in OV207 cells and proliferation in both cell lines. Verapamil has also been shown to reduce cancer cell migration in murine mammary carcinoma and human melanoma cell lines (Yohem et al. 1991, Todaro et al. 2003). In a phase II trial, the cytostatic inhibitor of calcium influx carboxyamidotriazole has been shown to stabilise some patients with EOC who had relapsed for between 6 and 13 months (Hussain et al. 2003). Our data also support inhibition of calcium influx as a possible therapeutic approach to combatting EOC progression.

There is increasing evidence that $\mathrm{PKC}$ is involved in gonadotropin-induced signalling in granulosa cells in a cAMP/PKA-independent manner (Pennybacker \& Herman 1991, Babu et al. 2000). In the present study, the PKC inhibitor GF 109203X significantly inhibited gonadotropin-induced ERK1/2 phosphorylation, migration and proliferation, demonstrating that EOCs are dependent on PKC signalling in a number of cellular processes. Using both pharmacological inhibition of PKC $\delta$ with rottlerin and the more targeted approach of gene-specific siRNA downregulation, we have shown that the calcium-independent PKC $\delta$ isoform is important for gonadotropin-induced ERK1/2 phosphorylation and proliferation. Rottlerin has been widely used and accepted as an inhibitor of PKC $\delta$, although its specificity has been questioned. It is significant that we were able to confirm the involvement of PKC $\delta$ using siRNA-mediated knockdown. Ohtani et al. (2001) have shown by broad pharmacological inhibition that PKC is involved in

Figure $7 \mathrm{FSH}$ - and $\mathrm{LH}$-induced proliferation requires activation of MAPK signalling and is regulated by calcium and PKC $\delta$.

(A) OV207 and (B) OVCAR-3 cells were treated with $10 \mathrm{nM}$ $\mathrm{FSH}$ or LH in the presence of either PD98059 (PD, $10 \mu \mathrm{M})$, verapamil (Vera, $25 \mu \mathrm{M}$ ) or GF 109203X (GFX, $100 \mathrm{nM}$ ) for 7 days, and proliferation was assessed by counting the cell number. (C) OVCAR-3 cells were transfected with either nonsilencing negative siRNA or PKC $\delta$-specific siRNA, and were treated with $10 \mathrm{nM} \mathrm{FSH}$ or LH. Proliferation was assessed after 7 days by direct cell counts. Cell proliferation is expressed as percentage relative to that of untreated control (ctl). Data are pooled mean \pm S.E.M. from three to five individual experiments performed in triplicate. ${ }^{\star \star} P<0.01$ versus untreated ctl;

${ }^{\star \star \star} P<0.001$ versus untreated ctl; ${ }^{\# \# \#} P<0.001$ versus $\mathrm{FSH}$ alone; ${ }^{+\dagger} P<0.001$ versus $\mathrm{LH}$ alone (by ANOVA). 
the growth stimulatory action of FSH on EOC cells and that FSH upregulates PKC $\alpha$, suggesting that this isoform may play a role in the proliferative effects of FSH. At least in OV207 cells, downregulation of PKC $\alpha$ with siRNA did not inhibit ERK phosphorylation. We have shown here that $\mathrm{PKC} \delta$ plays an important role in FSH- and LH-induced migration and proliferation of EOC.

$\mathrm{PKC} \delta$ has roles in a range of cell functions such as proliferation (as both a positive and negative regulator), differentiation, apoptosis (as both a positive and negative regulator) and tumour suppression (Jackson \& Foster 2004, Chen \& Chen 2009). In MCF-7 breast cancer cells, oestrogen-induced ERK1/2 activation and subsequent proliferation were blocked by inhibition of PKC $\delta$, demonstrating that PKC $\delta$ has the ability to activate the ERK1/2 cascade in another hormone-dependent cancer (Keshamouni et al. 2002). There is also evidence that $\mathrm{PKC} \delta$ can enhance cell motility, possibly by affecting the expression and activity of $\beta 1$ integrins and focal adhesion kinase (Chen et al. 2007, Brenner et al. 2008). Furthermore, $\mathrm{PKC} \delta$ has been shown to act to promote invasiveness in prostate and breast cancer cells (Kiley et al. 1999, Kharait et al. 2006, Villar et al. 2007), and rottlerin has been shown to completely prevent invasion induced by the integrin-activating peptide PHSRN in DU-125 prostate cancer cells (Zeng et al. 2006). We have shown that both FSH and LH induce migration in ovarian cancer cells that is dependent upon ERK1/2 and PKC $\delta$ signalling. In apparent contrast to our findings, Choi et al. (2006) have recently reported gonadotropin-induced invasion in SKOV-3 cells that was dependent on activation of matrix metalloproteases through PKA and PI3K pathways. It is possible that ERK1/2 and PKC $\delta$ might be critical for gonadotropin-induced cell motility in EOC cells, but may not be involved in proteolysis-dependent invasion.

The importance of both calcium and PKC $\delta$ in the activation of ERK1/2 has recently been described in cardiac fibroblasts. In these cells, angiotensin II-induced ERK1/2 activation has been shown to rely on both calcium- and PKC $\delta$-dependent mechanisms (Olson et al. 2008). Furthermore, angiotensinII-induced activation of Janus kinase 2 has also been shown to be dependent on $\mathrm{PKC} \delta$ and calcium involving Pyk2, a non-receptor tyrosine kinase which has been described as a convergence point between GPCRs and activation of the MAPK signalling pathway (Della Rocca et al. 1999, Frank et al. 2002). In HEK293 cells transfected with GnRH receptor, PKC $\delta$ and Pyk2 mediate GnRH-induced ERK1/2 activation (Farshori et al. 2003), indicating that PKC $\delta$ and Pyk2 may work cooperatively to activate ERK1/2 upon hormone-induced signalling.

The results of the present study suggest that both FSH and LH increase the migration and proliferation of EOC cells through activation of the MAPK/ERK1/2 pathway in a $\mathrm{PKC} \delta$ - and calcium-dependent manner. Targetting of these pathways and second messengers may offer new therapeutic options for the treatment of EOC.

\section{Supplementary data}

This is linked to the online version of the paper at http://dx. doi.org/10.1677/ERC-09-0152.

\section{Declaration of interest}

The authors declare that there is no conflict of interest that could be perceived as prejudicing the impartiality of the research reported.

\section{Funding}

This work was supported by the Cancer Institute NSW (Research Scholar Award to I Mertens-Walker and Fellowship to D J Marsh), a Cancer Memorial Research Scholarship from Royal North Shore Hospital, Sydney, Australia (to I Mertens-Walker) and the Cancer Council NSW.

\section{References}

Ali AS, Ali S, El-Rayes BF, Philip PA \& Sarkar FH 2009 Exploitation of protein kinase C: a useful target for cancer therapy. Cancer Treatment Reviews 35 1-8.

Babu PS, Krishnamurthy H, Chedrese PJ \& Sairam MR 2000 Activation of extracellular-regulated kinase pathways in ovarian granulosa cells by the novel growth factor type 1 follicle-stimulating hormone receptor. Role in hormone signaling and cell proliferation. Journal of Biological Chemistry 275 27615-27626.

Bilderback TR, Lee F, Auersperg N \& Rodland KD 2002 Phosphatidylinositol 3-kinase-dependent, MEK- independent proliferation in response to $\mathrm{CaR}$ activation. American Journal of Physiology. Cell Physiology 283 C282-C288.

Brenner W, Greber I, Gudejko-Thiel J, Beitz S, Schneider E, Walenta S, Peters K, Unger R \& Thuroff JW 2008 Migration of renal carcinoma cells is dependent on protein kinase Cdelta via beta1 integrin and focal adhesion kinase. International Journal of Oncology 32 1125-1131.

Chen CL \& Chen HC 2009 Functional suppression of E-cadherin by protein kinase Cdelta. Journal of Cell Science 122 513-523. 
Chen CL, Hsieh YT \& Chen HC 2007 Phosphorylation of adducin by protein kinase Cdelta promotes cell motility. Journal of Cell Science 120 1157-1167.

Choi KC, Kang SK, Tai CJ, Auersperg N \& Leung PC 2002 Follicle-stimulating hormone activates mitogen-activated protein kinase in preneoplastic and neoplastic ovarian surface epithelial cells. Journal of Clinical Endocrinology and Metabolism 87 2245-2253.

Choi JH, Choi KC, Auersperg N \& Leung PC 2005 Gonadotropins upregulate the epidermal growth factor receptor through activation of mitogen-activated protein kinases and phosphatidyl-inositol-3-kinase in human ovarian surface epithelial cells. Endocrine-Related Cancer 12 407-421.

Choi JH, Choi KC, Auersperg N \& Leung PC 2006 Gonadotropins activate proteolysis and increase invasion through protein kinase $\mathrm{A}$ and phosphatidylinositol 3-kinase pathways in human epithelial ovarian cancer cells. Cancer Research 66 3912-3920.

Choi JH, Chen CL, Poon SL, Wang HS \& Leung PC 2009 Gonadotropin-stimulated epidermal growth factor receptor expression in human ovarian surface epithelial cells: involvement of cyclic AMP-dependent exchange protein activated by cAMP pathway. Endocrine-Related Cancer 16 179-188.

Conover CA, Hartmann LC, Bradley S, Stalboerger P, Klee GG, Kalli KR \& Jenkins RB 1998 Biological characterization of human epithelial ovarian carcinoma cells in primary culture: the insulin-like growth factor system. Experimental Cell Research 238 439-449.

Cotton M \& Claing A 2009 G protein-coupled receptors stimulation and the control of cell migration. Cell Signalling 21 1045-1053.

Della Rocca GJ, Maudsley S, Daaka Y, Lefkowitz RJ \& Luttrell LM 1999 Pleiotropic coupling of G proteincoupled receptors to the mitogen-activated protein kinase cascade. Role of focal adhesions and receptor tyrosine kinases. Journal of Biological Chemistry 274 13978-13984.

Dempsey EC, Newton AC, Mochly-Rosen D, Fields AP, Reyland ME, Insel PA \& Messing RO 2000 Protein kinase $\mathrm{C}$ isozymes and the regulation of diverse cell responses. American Journal of Physiology. Lung Cellular and Molecular Physiology 279 L429-L438.

Deucher A, Efimova T \& Eckert RL 2002 Calciumdependent involucrin expression is inversely regulated by protein kinase C (PKC)alpha and PKCdelta. Journal of Biological Chemistry 277 17032-17040.

Dubeau L 2008 The cell of origin of ovarian epithelial tumours. Lancet Oncology 9 1191-1197.

Farshori PQ, Shah BH, Arora KK, Martinez-Fuentes A \& Catt KJ 2003 Activation and nuclear translocation of PKCdelta, Pyk2 and ERK1/2 by gonadotropin releasing hormone in HEK293 cells. Journal of Steroid Biochemistry and Molecular Biology 85 337-347.

Frank GD, Saito S, Motley ED, Sasaki T, Ohba M, Kuroki T, Inagami T \& Eguchi S 2002 Requirement of $\mathrm{Ca}(2+)$ and
PKCdelta for Janus kinase 2 activation by angiotensin II: involvement of PYK2. Molecular Endocrinology 16 367-377.

Gebauer G, Mueller N, Fehm T, Berkholz A, Beck EP, Jaeger W \& Licht P 2004 Expression and regulation of luteinizing hormone/human chorionic gonadotropin receptors in ovarian cancer and its correlation to human chorionic gonadotropin-doxorubicin sensitivity.

American Journal of Obstetrics and Gynecology 190 1621-1628.

Gnagy S, Ming EE, Devesa SS, Hartge P \& Whittemore AS 2000 Declining ovarian cancer rates in U.S. women in relation to parity and oral contraceptive use. Epidemiology 11 102-105.

Goldsmith ZG \& Dhanasekaran DN 2007 G protein regulation of MAPK networks. Oncogene 26 3122-3142.

Grant S, Qiao L \& Dent P 2002 Roles of ERBB family receptor tyrosine kinases, and downstream signaling pathways, in the control of cell growth and survival. Frontiers in Bioscience 7 d376-d389.

Hobson SA, McNeil SE, Lee F \& Rodland KD 2000 Signal transduction mechanisms linking increased extracellular calcium to proliferation in ovarian surface epithelial cells. Experimental Cell Research 258 1-11.

Hobson SA, Wright J, Lee F, McNeil SE, Bilderback T \& Rodland KD 2003 Activation of the MAP kinase cascade by exogenous calcium-sensing receptor. Molecular and Cellular Endocrinology 200 189-198.

Hsueh AJ, Adashi EY, Jones PB \& Welsh TH Jr 1984 Hormonal regulation of the differentiation of cultured ovarian granulosa cells. Endocrine Reviews 5 76-127.

Hussain MM, Kotz H, Minasian L, Premkumar A, Sarosy G, Reed E, Zhai S, Steinberg SM, Raggio M, Oliver VK et al. 2003 Phase II trial of carboxyamidotriazole in patients with relapsed epithelial ovarian cancer. Journal of Clinical Oncology 21 4356-4363.

Ivarsson K, Sundfeldt K, Brannstrom M, Hellberg P \& Janson PO 2001 Diverse effects of FSH and LH on proliferation of human ovarian surface epithelial cells. Human Reproduction 16 18-23.

Jackson DN \& Foster DA 2004 The enigmatic protein kinase Cdelta: complex roles in cell proliferation and survival. FASEB Journal 18 627-636.

Jemal A, Siegel R, Ward E, Hao Y, Xu J, Murray T \& Thun MJ 2008 Cancer statistics 2008. CA: A Cancer Journal for Clinicians 58 71-96.

Ji Q, Liu PI, Chen PK \& Aoyama C 2004 Follicle stimulating hormone-induced growth promotion and gene expression profiles on ovarian surface epithelial cells. International Journal of Cancer 112 803-814.

Keshamouni VG, Mattingly RR \& Reddy KB 2002 Mechanism of 17-beta-estradiol-induced Erk1/2 activation in breast cancer cells. A role for HER2 and PKC-delta. Journal of Biological Chemistry 277 22558-22565.

Kharait S, Dhir R, Lauffenburger D \& Wells A 2006 Protein kinase Cdelta signaling downstream of the EGF 
receptor mediates migration and invasiveness of prostate cancer cells. Biochemical and Biophysical Research Communications 343 848-856.

Kiley SC, Clark KJ, Duddy SK, Welch DR \& Jaken S 1999 Increased protein kinase $\mathrm{C}$ delta in mammary tumor cells: relationship to transformtion and metastatic progression. Oncogene 18 6748-6757.

Koivunen J, Aaltonen V \& Peltonen J 2006 Protein kinase C (PKC) family in cancer progression. Cancer Letters 235 $1-10$.

Konishi I 2006 Gonadotropins and ovarian carcinogenesis: a new era of basic research and its clinical implications. International Journal of Gynecological Cancer 16 16-22.

Lukanova A \& Kaaks R 2005 Endogenous hormones and ovarian cancer: epidemiology and current hypotheses. Cancer Epidemiology, Biomarkers and Prevention 14 98-107.

Martiny-Baron G, Kazanietz MG, Mischak H, Blumberg PM, Kochs G, Hug H, Marme D \& Schachtele C 1993 Selective inhibition of protein kinase $\mathrm{C}$ isozymes by the indolocarbazole Go 6976. Journal of Biological Chemistry 268 9194-9197.

McNeil L, Hobson S, Nipper V \& Rodland KD 1998 Functional calcium-sensing receptor expression in ovarian surface epithelial cells. American Journal of Obstetrics and Gynecology 178 305-313.

Modugno F, Ness RB, Allen GO, Schildkraut JM, Davis FG \& Goodman MT 2004 Oral contraceptive use, reproductive history, and risk of epithelial ovarian cancer in women with and without endometriosis. American Journal of Obstetrics and Gynecology 191 733-740.

Ohtani K, Sakamoto H, Kikuchi A, Nakayama Y, Idei T, Igarashi N, Matukawa T \& Satoh K 2001 Folliclestimulating hormone promotes the growth of human epithelial ovarian cancer cells through the protein kinase C-mediated system. Cancer Letters 166 207-213.

Olson ER, Shamhart PE, Naugle JE \& Meszaros JG 2008 Angiotensin II-induced extracellular signal-regulated kinase $1 / 2$ activation is mediated by protein kinase Cdelta and intracellular calcium in adult rat cardiac fibroblasts. Hypertension 51 704-711.

Parker PJ \& Murray-Rust J 2004 PKC at a glance. Journal of Cell Science 117 131-132.

Parrott JA, Doraiswamy V, Kim G, Mosher R \& Skinner MK 2001 Expression and actions of both the follicle stimulating hormone receptor and the luteinizing hormone receptor in normal ovarian surface epithelium and ovarian cancer. Molecular and Cellular Endocrinology 172 213-222.

Pennybacker M \& Herman B 1991 Follicle-stimulating hormone increases c-fos mRNA levels in rat granulosa cells via a protein kinase C-dependent mechanism. Molecular and Cellular Endocrinology 80 11-20.

Riman T, Nilsson S \& Persson IR 2004 Review of epidemiological evidence for reproductive and hormonal factors in relation to the risk of epithelial ovarian malignancies. Acta Obstetricia et Gynecologica Scandinavica 83 783-795.

Roderick HL \& Cook SJ $2008 \mathrm{Ca}^{2+}$ signalling checkpoints in cancer: remodelling $\mathrm{Ca}^{2+}$ for cancer cell proliferation and survival. Nature Reviews. Cancer 8 361-375.

Rzepka-Gorska I, Chudecka-Glaz A \& Kosmowska B 2004 FSH and LH serum/tumor fluid ratios and malignant tumors of the ovary. Endocrine-Related Cancer 11 315-321.

Schiffenbauer YS, Meir G, Maoz M, Even-Ram SC, Bar-Shavit R \& Neeman M 2002 Gonadotropin stimulation of MLS human epithelial ovarian carcinoma cells augments cell adhesion mediated by CD44 and by alpha(v)-integrin. Gynecologic Oncology 84 296-302.

Slot KA, de Boer-Brouwer M, Houweling M, Vaandrager AB, Dorrington JH \& Teerds KJ 2006 Luteinizing hormone inhibits Fas-induced apoptosis in ovarian surface epithelial cell lines. Journal of Endocrinology 188 227-239.

Syed V, Ulinski G, Mok SC, Yiu GK \& Ho SM 2001 Expression of gonadotropin receptor and growth responses to key reproductive hormones in normal and malignant human ovarian surface epithelial cells. Cancer Research 61 6768-6776.

Thomas CM, Boss EA, Boonstra H, van Tienoven D, Sweep CG \& Massuger LF 2008 Gonadotropins and female sex steroid hormones in cyst fluid and serum from patients with ovarian tumors. European Journal of Gynaecological Oncology 29 468-472.

Todaro LB, Ladeda V, Bal de Kier Joffe E \& Farias EF 2003 Combined treatment with verapamil, a calcium channel blocker, and B428, a synthetic uPA inhibitor, impairs the metastatic ability of a murine mammary carcinoma. Oncology Reports 10 725-732.

Touyz RM, Jiang L \& Sairam MR 2000 Follicle-stimulating hormone mediated calcium signaling by the alternatively spliced growth factor type I receptor. Biology of Reproduction 62 1067-1074.

Uberall F, Giselbrecht S, Hellbert K, Fresser F, Bauer B, Gschwendt M, Grunicke HH \& Baier G 1997 Conventional PKC-alpha, novel PKC-epsilon and PKC-theta, but not atypical PKC-lambda are MARCKS kinases in intact NIH 3T3 fibroblasts. Journal of Biological Chemistry 272 4072-4078.

Villar J, Arenas MI, MacCarthy CM, Blanquez MJ, Tirado OM \& Notario V 2007 PCPH/ENTPD5 expression enhances the invasiveness of human prostate cancer cells by a protein kinase $\mathrm{C}$ delta-dependent mechanism. Cancer Research 67 10859-10868.

Viswanath G, Chatterjee S \& Roy P 2007 Assessment of luteinizing hormone receptor function in an endometrial cancer cell line, Ishikawa cells in response to human chorionic gonadotrophin (hCG). Molecular and Cellular Endocrinology 272 14-21.

Wimalasena J, Dostal R \& Meehan D 1992 Gonadotropins, estradiol, and growth factors regulate epithelial ovarian cancer cell growth. Gynecologic Oncology 46 345-350. 
Wright JW, Toth-Fejel S, Stouffer RL \& Rodland KD 2002 Proliferation of rhesus ovarian surface epithelial cells in culture: lack of mitogenic response to steroid or gonadotropic hormones. Endocrinology 143 2198-2207.

Yohem KH, Clothier JL, Montague SL, Geary RJ, Winters AL III, Hendrix MJ \& Welch DR 1991 Inhibition of tumor cell invasion by verapamil. Pigment Cell Research 4 225-233.

Yoon S \& Seger R 2006 The extracellular signal-regulated kinase: multiple substrates regulate diverse cellular functions. Growth Factors 24 21-44.

Zeng ZZ, Jia Y, Hahn NJ, Markwart SM, Rockwood KF \& Livant DL 2006 Role of focal adhesion kinase and phosphatidylinositol $3^{\prime}$-kinase in integrin fibronectin receptor-mediated, matrix metalloproteinase-1-dependent invasion by metastatic prostate cancer cells. Cancer Research 66 8091-8099.

Zhang XY, Chen J, Zheng YF, Gao XL, Kang Y, Liu JC, Cheng MJ, Sun H \& Xu CJ 2009 Follicle-stimulating hormone peptide can facilitate paclitaxel nanoparticles to target ovarian carcinoma in vivo. Cancer Research 69 6506-6514.

Zheng W, Lu JJ, Luo F, Zheng Y, Feng Y, Felix JC, Lauchlan SC \& Pike MC 2000 Ovarian epithelial tumor growth promotion by follicle-stimulating hormone and inhibition of the effect by luteinizing hormone. Gynecologic Oncology 76 80-88. 